\title{
STUDI EKSPLORASI FASILITAS WORKSHOP TEKNIK OTOMOTIF SMK NEGERI 2 GARUT BERDASARKAN STANDAR SARANA PRASARANA
}

\author{
Faisal Rahman ${ }^{1}$, Dedi Supriawan ${ }^{2}$, Tatang Permana ${ }^{3}$ \\ Departemen Pendidikan Teknik Mesin \\ Universitas Pendidikan Indonesia \\ Jl. Dr. Setiabudhi No. 207 Bandung 40154 \\ rahmanchale@gmail.com
}

\begin{abstract}
ABSTRAK
Tujuan penelitian ini adalah untuk memperoleh gambaran tentang sarana dan prasarana di workshop Teknik Mekanik Otomotif SMK Negeri 2 Garut dan pemenuhan standar uji kompetensi Teknik Mekanik Otomotif SMK berdasarkan instrumen verifikasi SMK penyelenggara ujian praktik kejuruan. Penelitian ini mengambil lokasi di workshop Otomotif SMK Negeri 2 Garut. Metode yang digunakan adalah metode deskriptif dengan pendekatan kuantitatif. Instrumen penelitian yang digunakan peneliti adalah hasil dari observasi dan dokumentasi, berupa pedoman observasi/checklist. Hasil penelitian menunjukkan bahwa (1) Sarana di workshop Teknik Mekanik Otomotif SMKN 2 Garut 85,7\% telah memenuhi Standar Nasional Pendidikan. (2) Prasarana di workshop Teknik Mekanik Otomotif SMKN 2 Garut 50\%g sudah memenuhi Standar Nasional Pendidikan atau kategori kurang layak. (3) Sarana dan prasarana yang terdapat di workshop Teknik Mekanik Otomotif SMKN 2 Garut 98,7\% telah memenuhi standar uji kompetensi. Kesimpulan penelitian ini SMKN 2 Garut sangat layak untuk dijadikan tempat pelaksanaan ujian kompetensi.
\end{abstract}

Kata kunci: sarana, prasarana, standard, otomotif

\begin{abstract}
The purposes of this research are: 1) obtain an overview of workshop facilities at automotive class State Vocational School 2 Garut; 2) obtain an overview of workshop infrastructure at automotive class; 3) obtain an overview of the infrastructure and facilities in Automotive Engineering Workshop towards standards compliance testing Automotive Engineering vocational competency based vocational Verification Instrument Operator Exam Practice Vocational . The research conducted at State Vocational School 2 Garut. The method was descriptive with quantitative approach. Whereas the instrument were documentation and observation. The result showed that; (1) The facilities of workshop at automotive class of State Vocational School 2 Garut has fulfilled the national standard with the percentages $85,7 \%$. (2) The infrastructures of workshop at automotive class of State Vocational School 2 Garut has fulfilled the national standard with the percentages $50 \%$ (3) Facilities and infrastructures at automotive class of State Vocational School 2 Garut was eligible to be a place of competency test because the number achievement was $98,7 \%$. It fulfilled the standard competence tests.
\end{abstract}

Keywords: facilities, infrastructures, standard, automotive

\footnotetext{
${ }^{1}$ Mahasiswa Departemen Pendidikan Teknik Mesin FPTK UPI

${ }^{2}$ Dosen Departemen Pendidikan Teknik Mesin FPTK UPI

${ }^{3}$ Dosen Departemen Pendidikan Teknik Mesin FPTK UPI
} 


\section{PENDAHULUAN}

SMK yang sekarang ini sedang dikembangkan oleh pemerintah, tentu sangat diharapkan menghasilkan lulusan SMK yang berprestasi, berdaya guna, siap pakai, mampu bersaing, dan mempunyai kompetensi tinggi untuk bersaing di dunia usaha dan dunia industri. Peningkatan prestasi siswa khususnya lulusan SMK sangat diharapkan, salah satu faktor peningkatan prestasi siswa adalah lengkapnya sarana dan prasarana yang dimiliki oleh sekolah itu sendiri. Dijelaskan dalam Peraturan Menteri Pendidikan Nasional Republik Indonesia No 40/2008 bahwa Penyelenggara Sekolah Menengah Kejuruan/Madrasah Aliyah Kejuruan (SMK/MAK) wajib menerapkan standar sarana dan prasarana. Peraturan ini menjelaskan tentang kewajiban bagi setiap lembaga pendidikan khususnya SMK dan MAK untuk memenuhi standar sarana prasarana agar tujuan pendidikan bisa tercapai dan juga standar sarana prasarana ini sangat berpengaruh terhadap kualitas lulusan. Lengkap tidaknya perlengkapan belajar baik yang dimiliki siswa maupun yang dimiliki sekolah menimbulkan hasil tertentu terhadap hasil belajar siswa. Kekurangan peralatan dapat membawa akibat negatif antara lain siswa tidak bisa belajar secara baik sehingga sulit diharapkan mencapai prestasi tinggi.

Lingkungan fisik tempat belajar mempunyai pengaruh penting terhadap hasil pembelajaran. Lingkungan fisik yang menguntungkan dan memenuhi syarat minimal mendukung meningkatnya intensitas proses pembelajaran dan mempunyai pengaruh positif terhadap pencapaian tujuan pengajaran. Kelengkapan sarana prasarana di SMK khususnya perlengkapan sarana prasarana workshop Otomotif di SMK Negeri 2 Garut sangatlah berpengaruh terhadap pencapaian kompetensi. Sehingga dapat mengakibatkan proses pembelajaran praktikum pada mata pelajaran otomotif di workshop otomotif menjadi kurang kondusif. Sarana dan prasarana yang tersedia di SMK bisa sesuai Standar Nasional Pendidikan tentang Standar Sarana Prasarana.

Berdasarkan hasil pengamatan awal penulis, secara visual workshop otomotif di SMK Negeri 2 Garut masih kurang memadai. Hal ini terlihat jelas ketika pengamatan pertama ke workshop Otomotif terutama pada area kerja kelistrikan yang kurang sesuai dengan standar. Hasil pengamatan pertama yaitu area kerja kelistrikan jumlah siswa 36, luas $50 \mathrm{~m}^{2}$, lebar $5 \mathrm{~m}$, panjang $10 \mathrm{~m}$, maka $1,4 \mathrm{~m}^{2} /$ peserta didik.

Perlengkapan sarana dan prasarana tersebut yang menurut penulis sangat penting> Hal ini berdampak pada kompetensi yang dimiliki lulusan SMK dituntut untuk kompeten di bidangnya. Idealnya kompetensi lulusan SMK itu sendiri bisa sesuai tuntutan dunia usaha dan dunia industri (Moeheriono, 2010). Begitupun terhadap kelengkapan sarana dan 
prasarana yang idealnya minimum sesuai dengan tuntutan standar untuk SMK. Berdasarkan kajian tersebut perlu diteliti kesesuaian sarana dan prasarana yang terdapat di workshop Otomotif. Tujuan dari penelitian ini adalah sebagai berikut: memperoleh gambaran tentang sarana dan prasarana di workshop Teknik Mekanik Otomotif SMK Negeri 2 Garut terhadap pemenuhan standar uji kompetensi Teknik Mekanik Otomotif SMK berdasarkan Instrumen Verifikasi SMK Penyelenggara Ujian Praktik Kejuruan.

Workshop/bengkel dapat diartikan sebagai tempat pelaksanaan kegiatan belajar mengajar keterampilan. Bengkel bukan hanya berarti bengkel tempat praktik peserta didik, tetapi juga berarti tempat para instruktur mengajarkan keterampilan kepada para peserta didik agar mereka mencapai tujuan belajar secara efektif dan efisien. Workshop/bengkel sangat berperan penting dalam proses belajar mengajar di SMK, khususnya teknik otomotif itu sendiri. Adapun yang dimaksud dengan bengkel disini adalah suatu tempat dimana dilakukan perbaikan-perbaikan yang bersifat teknis terhadap suatu produk yang dalam konteks materi ini, produk yang dimaksud adalah kendaraan bermotor (Permana, 2012).

Sarana pendidikan dapat diklasifikasikan menjadi tiga macam, yaitu berdasarkan habis tidaknya, berdasarkan bergerak tidaknya, dan berdasarkan hubungan dengan proses pembelajaran (Barnawi dan Arifin, 2012). Apabila dilihat dari bergerak atau tidaknya pada saat pembelajaran juga ada dua macam, yaitu bergerak dan tidak bergerak. Sementara jika dilihat dari hubungan sarana tersebut terhadap proses pembelajaran ada tiga macam, yaitu alat pelajaran, alat peraga, dan media pembelajaran

a. Klasifikasi standar sarana area kerja, terdiri dari: area kerja mesin otomotif, area kerja kelistrikan, area kerja chassis, area kerja pemindah tenaga, dan ruang instruktur dan penyimpanan.

b. Klasifikasi Peralatan, terdiri dari:

1) Alat tangan, yaitu seperangkat alat yang digunakan untuk membantu dalam penyelesaian pekerjaan, misalnya: obeng, tang, kunci pas dan lain-lain.

2) Alat tangan yang memiliki daya (power tools), yaitu seperangkat alat yang digunakan untuk membantu dalam menyelesaikan pekerjaan yang memerlukan ketelitian/kecermatan, misalnya: mesin ampelas, mesin gerinda dan lain-lain.

3) Alat ukur (measuring) dan uji, yaitu peralatan yang merupakan hasil rakitan dan atau perbaikan.

4) Peralatan mesin

5) Alat bantu mengajar dan peralatan umum (teaching aids) 
6) Training object/simulator, yaitu mesin atau objek latihan praktik yang dibuat secara simulasi dalam bentuk rangkaian, model atau bagian dari sistem sebuah kendaraan yang dioperasikan sesuai dengan kondisi yang sebenarnya.

Prasarana pendidikan merupakan penunjang proses pendidikan di sekolah. Prasarana pendidikan di sekolah dapat diklasifikasikan menjadi dua macam, yaitu prasarana langsung dan prasarana tidak langsung. Seperti yang digambarkan pada tabel di bawah ini tentang klasifikasi sarana dan prasarana pendidikan. Prasarana langsung adalah prasarana yang secara langsung digunakan dalam proses pembelajaran, misalnya ruang kelas, ruang laboratorium, ruang praktik, dan ruang komputer. Prasarana tidak langsung adalah prasarana yang tidak digunakan dalam proses pembelajaran, tetapi sangat menunjang proses pembelajaran, misalnya ruang kantor, kantin, tanah, dan jalan menuju sekolah, kamar kecil, ruang UKS, ruang guru, ruang kepala sekolah, taman, dan tempat parkir kendaraan (BSNP, 2014).

Kompetensi merupakan evalusi hasil belajar siswa selama belajar dan bisa dijadikan sebagai alat ukur keberhasilan siswa dan guru dalam melaksanakan pembelajaran di sebuah sekolah. Awalnya kegiatan uji kompetensi ini akan dilaksanakan sebelum Ujian Nasional. Uji kompetensi adalah suatu sarana untuk menguji kemampuan siswa apakah siswa ini kompeten atau tidak kompeten di dalam mata diklat yang telah diberikan. Pembelajaran berbasis kompetensi adalah pembelajaran yang dilakukan dengan orientasi pencapaian peserta didik, sehingga muara akhir hasil pembelajaran adalah meningkatnya kompetensi peserta didik yang dapat diukur dalam pola sikap, pengetahuan, dan keterampilannya (Daryanto, 2013).

\section{METODE PENELITIAN}

Metode yang digunakan dalam penelitian ini yaitu menggunakan penelitian deskriptif, dengan pendekatan kuantitatif. Penelitian ini mengambil lokasi di workshop Otomotif SMK Negeri 2 Garut. Subyek penelitian dalam penelitian ini yaitu guru produktif khususnya kepala bengkel, dan objek penelitiannya yaitu tentang sarana dan prasarana praktik otomotif. Teknik pengumpulan data dalam penelitian ini menggunakan teknik observasi, dan dokumentasi. Teknik analisis data dalam penelitian ini menggunakan statistik deskriptif. 


\section{HASIL PENELITIAN}

Diagram ketercapaian sarana prasarana yang disesuaikan terhadap Peraturan Menteri Pendidikan Nasional Nomor 40 Tahun 2008 Tentang Standar Sarana dan Prasarana Sekolah Menengah Kejuruan/Madrasah Aliyah Kejuruan dan Instrumen Verifikasi SMK Penyelenggara Ujian Praktik Kejuruan dari BSNP.

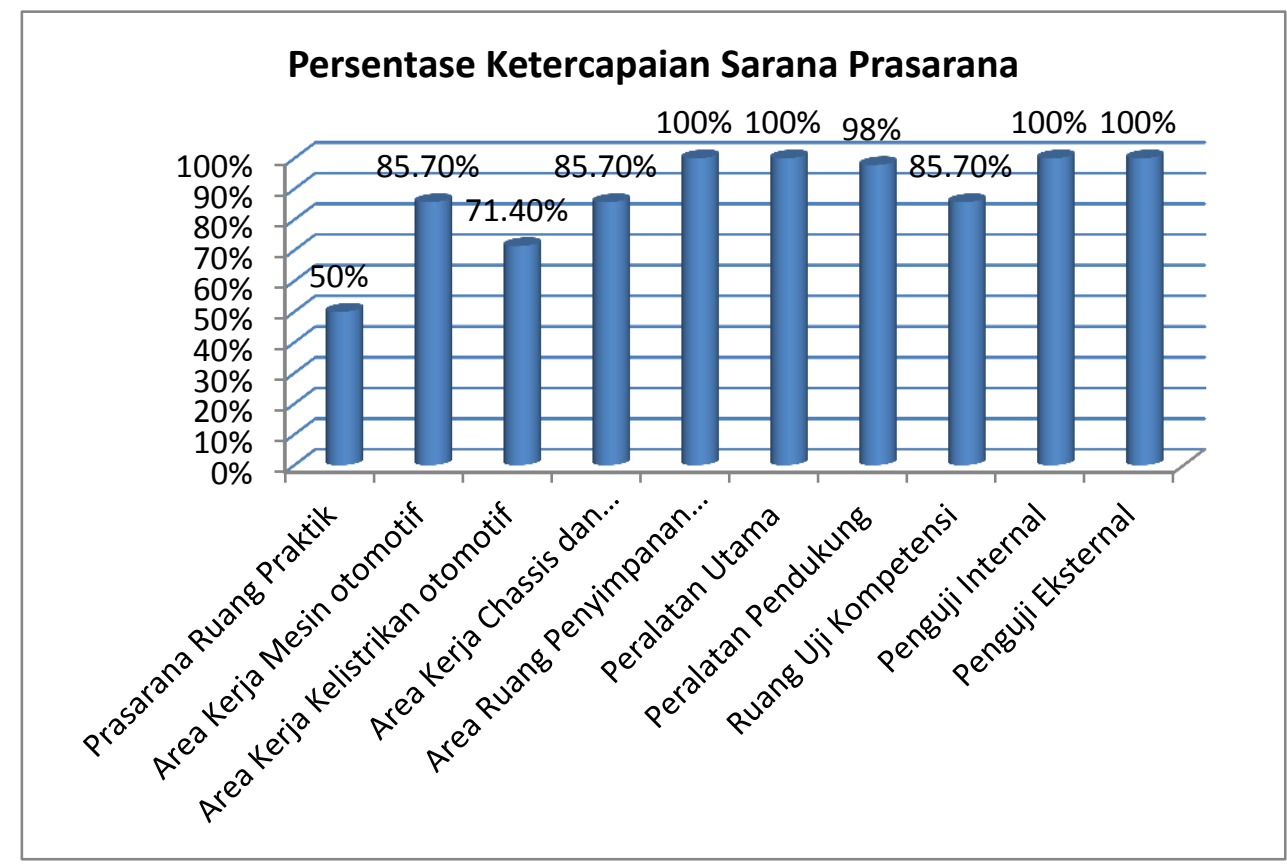

Gambar 1. Diagram ketercapaian sarana dan prasarana ruang praktik di workshop otomotif

Hasil observasi dan dokumentasi, pencapaian standar sarana dan prasarana secara keseluruhan di Workshop otomotif mencapai:

a. Prasarana ruang praktik : 50\% (kurang layak/kurang lengkap)

b. Sarana ruang praktik $: 85,7 \%$ (sangat layak/sangat lengkap)

c. Standar uji kompetensi : 96,7\% (sangat layak/sangat lengkap)

Hasil observasi dan dokumentasi di atas yang disesuaikan terhadap Instrumen Verifikasi SMK Penyelenggara Ujian Praktik Kejuruan dari BSNP., maka untuk sarana dan prasarana yang terdapat di Workshop Teknik Mekanik Otomotif SMK Negeri 2 Garut bisa memenuhi standar uji kompetensi dengan ketercapaian 96,7\%. Artinya sangat layak untuk dijadikan tempat pelaksanaan ujian kompetensi.

\section{PEMBAHASAN}

Data yang disajikan ini merupakan hasil dari studi kasus terhadap sarana dan prasarana workshop otomotif yang terdapat di Workshop Teknik Mekanik Otomotif SMK Negeri 2 Garut. Adapun data yang diteliti dari penelitian ini disesuaikan dengan standar 
sarana dan prasarana berdasarkan Permendiknas RI No. 40 Tahun 2008 dan instrumen verifikasi SMK penyelenggara ujian praktik kejuruan dari BSNP. Data yang diteliti diantaranya meliputi sarana dan prasarana di area kerja mesin otomotif, area kerja kelistrikan otomotif, area kerja chassis dan pemindah tenaga, ruang penyimpanan dan instruktur, serta standar uji kompetensi yang meliputi peralatan utama, peralatan pendukung, tempat/ruang pelaksanaan uji kompetensi, serta tim penguji internal dan eksternal.

Kondisi sarana di area kerja mesin otomotif menunjukkan bahwa sarana di area kerja mesin otomotif belum sepenuhnya sesuai standar, terlihat jelas pada kursi kerja/stool dengan perbandingan terhadap jumlah siswa sebanyak 36 siswa. Persentase untuk tingkat pencapaian standar prasarana di area kerja otomotif mencapai 85,7\%. Artinya tingkat ketercapaian untuk standar sarana di area kerja mesin otomotif sebagian besar tercapai yaitu sangat layak/sangat lengkap. Hal tersebut sesuai dengan Peraturan Menteri Pendidikan Nasional Nomor 40 Tahun 2008 Tentang Standar Sarana dan Prasarana Sekolah Menengah Kejuruan/Madrasah Aliyah Kejuruan.

Kondisi sarana di area kerja kelistrikan otomotif menunjukkan bahwa sarana di area kerja mesin otomotif belum sepenuhnya sesuai standar, terlihat jelas pada meja kerja dan kursi kerja/stool dengan perbandingan terhadap jumlah siswa sebanyak 36 siswa. Persentase untuk tingkat pencapaian standar sarana di area kerja kelistrikan otomotif mencapai 71,4\%. Artinya tingkat ketercapaian untuk standar sarana di area kerja kelistrikan otomotif pada workshop Otomotif dinyatakan layak/lengkap. Sehingga sesuai dengan Peraturan Menteri Pendidikan Nasional Nomor 40 Tahun 2008 Tentang Standar Sarana dan Prasarana Sekolah Menengah Kejuruan/Madrasah Aliyah Kejuruan.

Kondisi sarana di area kerja chassis dan pemindah tenaga menunjukkan bahwa sarana di area kerja chassis dan pemindah tenaga belum sepenuhnya sesuai standar. Dapat dilihat pada kursi kerja/stool dengan perbandingan terhadap jumlah siswa sebanyak 36 siswa. Persentase untuk tingkat pencapaian standar prsarana di area kerja otomotif mencapai $85,7 \%$. Aartinya tingkat ketercapaian untuk standar sarana di area kerja chassis dan pemindah tenaga otomotif di workshop Otomotif dinyatakan sangat layak/sangat lengkap. Hal tersebut telah sesuai dengan Peraturan Menteri Pendidikan Nasional Nomor 40 Tahun 2008 Tentang Standar Sarana dan Prasarana Sekolah Menengah Kejuruan/Madrasah Aliyah Kejuruan.

Kondisi sarana di ruang penyimpanan dan instruktur menunjukkan bahwa sarana di ruang penyimpanan dan instruktur sudah sepenuhnya sesuai standar, dengan perbandingan 
terhadap jumlah instruktur sebanyak 12 instruktur. Persentase untuk tingkat pencapaian standar sarana ruang penyimpanan dan instruktur mencapai 100\%. Artinya tingkat ketercapaian untuk standar sarana di ruang penyimpanan dan instruktur di workshop Otomotif dinyatakan sangat layak/sangat lengkap. Hal tersebu telah sesuai dengan Peraturan Menteri Pendidikan Nasional Nomor 40 Tahun 2008 Tentang Standar Sarana dan Prasarana Sekolah Menengah Kejuruan/Madrasah Aliyah Kejuruan.

Kondisi prasarana di area kerja otomotif menunjukkan bahwa standar prasarana belum sepenuhnya tercapai, ada beberapa yang tidak sesuai standar dengan perbandingan terhadap jumlah siswa sebanyak 36 siswa, diantaranya pada area kerja kelistrikan otomotif dan area kerja chassis dan pemindah tenaga. Persentase untuk tingkat pencapaian standar prasarana di area kerja otomotif mencapai 50\%. Artinya tingkat ketercapaian untuk standar prasarana di workshop Otomotif dinyatakan kurang layak/kurang lengkap yang disesuaikan terhadap Peraturan Menteri Pendidikan Nasional Nomor 40 Tahun 2008 Tentang Standar Sarana dan Prasarana Sekolah Menengah Kejuruan/Madrasah Aliyah Kejuruan.

Peralatan utama sudah sepenuhnya sesuai standar, dengan perbandingan skala 1 sampai 3 yaitu tidak layak, layak, dan sangat layak terhadap tingkat kualitas spesifikasi alat, jumlah alat, dan kondisi alat. Persentase untuk tingkat pencapaian standar persyaratan peralatan utama untuk uji kompetensi terhadap kualitas spesifikasi alat mencapai $100 \%$. Prosentase tingkat pencapaian standar persyaratan peralatan utama untuk uji kompetensi terhadap kualitas jumlah alat mencapai 100\%. Kemudian prosentase tingkat pencapaian standar persyaratan peralatan utama untuk uji kompetensi terhadap kualitas kondisi alat mencapai 100\%. Secara keseluruhan tercapai sebesar 100\%. Artinya tingkat ketercapaian untuk standar peralatan utama uji kompetensi di workshop Otomotif dinyatakan sangat layak dengan mendapat skor 3 yang disesuaikan terhadap Instrumen Verifikasi SMK Penyelenggara Ujian Praktik Kejuruan dari BSNP.

Standar persyaratan peralatan pendukung untuk uji kompetensi menunjukkan bahwa peralatan pendukung sudah sepenuhnya sesuai standar, dengan perbandingan skala 1 sampai 3 yaitu tidak layak, layak, dan sangat layak terhadap tingkat kualitas spesifikasi alat, jumlah alat, dan kondisi alat. Persentase untuk tingkat pencapaian standar persyaratan peralatan pendukung untuk uji kompetensi terhadap kualitas spesifikasi alat mencapai $100 \%$. Prosentase tingkat pencapaian standar persyaratan peralatan pendukung untuk uji kompetensi terhadap kualitas jumlah alat mencapai 95\%. Prosentase tingkat pencapaian standar persyaratan peralatan pendukung untuk uji kompetensi terhadap kualitas kondisi alat mencapai 97,8\%. Secara keseluruhan tercapai sebesar 97,8\%. Artinya tingkat 
ketercapaian untuk standar peralatan pendukung uji kompetensi di workshop Otomotif dinyatakan sangat layak dengan mendapat skor 2,93 yang disesuaikan terhadap Instrumen Verifikasi SMK Penyelenggara Ujian Praktik Kejuruan dari BSNP.

Standar persyaratan tempat/ruang untuk uji kompetensi menunjukkan bahwa persyaratan tempat/ruang sudah sepenuhnya sesuai standar, dengan perbandingan skala 1 sampai 3 yaitu tidak layak, layak, dan sangat layak. Prosentase untuk tingkat pencapaian standar persyaratan tempat/ruang untuk uji kompetensi mencapai 85,7\%. Artinya tingkat ketercapaian untuk standar persyaratan tempat/ruang uji kompetensi di workshop Otomotif dinyatakan sangat layak dengan mendapat skor 2,6 yang disesuaikan terhadap Instrumen Verifikasi SMK Penyelenggara Ujian Praktik Kejuruan dari BSNP.

Standar persyaratan penguji internal untuk uji kompetensi menunjukkan bahwa persyaratan penguji internal sudah sepenuhnya sesuai standar, dengan perbandingan skala 1 sampai 3 yaitu tidak layak, layak, dan sangat layak. Prosentase untuk tingkat pencapaian standar persyaratan penguji internal untuk uji kompetensi mencapai 100\%. Artinya tingkat ketercapaian untuk standar persyaratan penguji internal uji kompetensi di workshop Otomotif dinyatakan sangat layak dengan mendapat skor 3 yang disesuaikan terhadap Instrumen Verifikasi SMK Penyelenggara Ujian Praktik Kejuruan dari BSNP.

Standar persyaratan penguji eksternal untuk uji kompetensi menunjukkan bahwa persyaratan penguji eksternal sudah sepenuhnya sesuai standar, dengan perbandingan skala 1 sampai 3 yaitu tidak layak, layak, dan sangat layak. Persentase untuk tingkat pencapaian standar persyaratan penguji eksternal untuk uji kompetensi mencapai 100\%. artinya tingkat ketercapaian untuk standar persyaratan penguji eksternal uji kompetensi di workshop Otomotif dinyatakan sangat layak dengan mendapat skor 3 yang disesuaikan terhadap Instrumen Verifikasi SMK Penyelenggara Ujian Praktik Kejuruan dari BSNP.

\section{KESIMPULAN}

Kesimpulan penelitian ini, sebagai berikut: sarana di workshop Teknik Mekanik Otomotif SMK Negeri 2 Garut sudah memenuhi Standar Nasional Pendidikan dengan ketercapaian 85,7\%. Artinya sangat layak/sangat lengkap yang disesuaikan terhadap Peraturan Menteri Pendidikan Nasional Nomor 40 Tahun 2008. Prasarana di workshop belum memenuhi Standar Nasional Pendidikan dengan ketercapaian 50\%. Arang artinya kurang layak/kurang lengkap yang disesuaikan terhadap Peraturan Menteri Pendidikan Nasional Nomor 40 Tahun 2008. Sarana dan prasarana yang terdapat di workshop Teknik memenuhi standar uji kompetensi dengan dengan ketercapaian 98,7\%. Artinya sangat 
lengkap/sangat layak untuk dijadikan tempat pelaksanaan ujian kompetensi yang disesuaikan dengan standar BSNP.

\section{DAFTAR PUSTAKA}

Barnawi \& Arifin, M. (2012). Manajemen Sarana dan Prasarana Sekolah. Jogjakarta: ArRuzz Media.

BSNP. (2014). Instrumen Verifikasi SMK Penyelenggara Ujian Praktik Kejuruan. Jakarta: Kemdikbud.

Daryanto. (2013). Strategi Tahapan Mengajar dan Bekal Keterampilan Dasar bagi Guru. Bandung: CV Yrama Widya.

Moeheriono. (2010). Pengukuran Kinerja Berbasis Kompetensi. Bogor: Ghalia Indonesia.

Permana, T. (2012) Bab I Bengkel Otomotif. [Online]. Diakses: Sumber:http://file.upi.edu/browse.php?dir=Direktori/FPTK/JUR._PEND._TEKNI K_MESIN/196511101992031-TATANG_PERMANA/ 